\title{
Travel Disadvantage in Selected Rural Border Communities of Oyo State, Nigeria
}

\section{Popoola Kehinde Olayinka}

\author{
Department of Urban and Regional Planning, Obafemi Awolowo University
} Ile-Ife, Nigeria; yinkaolayiwola@yahoo.co.uk

\author{
Doi:10.5901/ajis.2016.v5n2p123
}

\begin{abstract}
The study examined travel disadvantage in selected rural border communities of Oyo State, Nigeria. Multi-stage sampling technique was used for the survey. Two local government areas were selected from the border State (Oyo State) on the basis of their closeness to the border. Four rural border settlements were selected from each of the selected local government areas through simple random selection process. This was followed by selection of every third house in the respective settlements after the first house was randomly selected. A total of 115 duly completed questionnaires administered to the household head in each sampled household were used. It was discovered in the study that majority (94\%) of the residents move around by trekking with $65 \%$ of the respondents trekking long distances between $1 \mathrm{~km}$ and $5 \mathrm{~km}$ daily. The major reason for the travel disadvantage situation was attributed to the bad condition of the roads which restricts the movement of vehicle. However, in other to salvage the situation, the residents used communal labour to create new paths or widen the existing ones for easy passage of vehicles and passengers. Also the residents sold their products at extremely low prices to middlemen from towns. This study therefore concluded that transport situation in rural border areas of Nigeria needs urgent attention to ensure the liveability of the area and its economic development.
\end{abstract}

Keywords: Travel, Travel disadvantage, Rural areas, Rural Border areas.

\section{Introduction}

One of the major prerequisites of efficient functioning of a place is the facility for movement of people, goods and services as quickly and economically (Filani, 1988). According to (Fadare and Salami, 2004), the need to travel from one place to another is necessitated by the spatial spread of activities within a geographical space. In other words, transport is very important for spatial interactions and economic development and it is also the engine of growth in any economy. However, transportation in rural communities constitute major challenges in Nigeria and this is even worse off in rural border communities of the country.

Rural border communities like many other rural communities in Nigeria are transport disadvantaged. The roads in many of these areas are in deplorable conditions and most of the villages are cut off due to the bad state of the roads. For instance, many of the roads are narrow, untarred with ditch like portholes and are usually worse in rainy season. Also many of these communities have no organized public transport, therefore majority of the residents trek to move around. These transport challenges generally in Nigeria are so enormous and have therefore prompted the federal, state and local governments in the country to set up programmes for transport improvement and development in the country (Adeyemi, 2001). For instance in 2004, National Economic Empowerment and Development Strategy" (NEEDS) was launched by the government as explained by Adedeji et al (2014). One of the major objectives of the strategy was to improve the transport Infrastructure through road construction and its maintenance to enhance movement of people, goods and services. Adedeji et al (2014) further explained that the Federal Government also prepared a National Policy on Rural Travel and Transport (NPRTT) which was aimed at improving rural access and mobility. However, in spite of all these efforts by the government, rural transport are still in the same deplorable condition. This work therefore focus on travel disadvantage in rural border communities of South West Nigeria.

\section{Theoretical Issues}

Travel disadvantage according to Travers (1992) is a situation where people have frequent mobility or access problems. It is a condition of disadvantage (social, economic, labour market, housing) in which transport plays a strong role (Dodson, et al 2004). It also embraces all difficulties associated with access to transport (Child Family Community Australia (CFCA) Resource Sheet, 2011). The ability to move around depends on several factors like; transport services, 
individual resources like time, cost, physical capacity, poor physical accessibility, and also the spatial distribution of activity destinations (Giuliano, 2003). All these factors constitute major challenges to travel in the country. These travel challenges limit the ability of people to move around and harness different opportunities. For instance, Adedeji et al (2014) explained that the major travel problems in the rural areas are the means to meet the demands of the people for goods to be conveyed to different geographic locations. This is also the same situation in most rural border communities of Nigeria. This transport situation according to Anele (2012) can be attributed to corruption and structural anomalies in local government administration and finance which prevents the local government from tackling the problems of poverty and underdevelopment in the areas.

Deike (1998) categorized rural travel into three; (i) Domestic travel like water and firewood collection (ii) Agricultural travel like field and market trips (iii) Service and Social purposes travel like travel to health facilities and church. Rural households have different travel needs. These rural travel needs according to Oyeleye et al (2013) are categorized into two. They are: "on farm" and "off farm". Travel needs relating to on farm activities includes travel for domestic needs such as collection of water and firewood along with other farm related travel. Off farm travel are access to the markets and other services like schools and health centres. However in a bit for the rural residents to access their needs, they are disadvantaged.

Efficient and functional transportation system is very important in any country especially the border communities of the country. Border communities according to Benneth (2009) are communities closer to the international border line between two countries, states or regions. Border communities in Africa have a lot of setbacks such as insecurity, smuggling, and vulnerability to disease (Weber, 2012; Bonchuck, 2014).They are characterized by neglect especially in the provision of infrastructural facilities. Specifically in Nigeria, most of the border communities are under-developed with majority of the residents being faced with enormous challenges in moving around. In other words, they are transport disadvantaged.

Border communities are very sensitive and strategic areas of the country. The strategic place the borders of a country holds has been recognized by many authors (Bonchuk, 2014; Bonchuk, 2012; Weber, 2012; Agbo, 2011; Tandia, 2010; Afolayan, 2010; Adepoju, 2005). For instance, Tandia (2010) sees the border area as areas that sanctions the state's sovereignty and authority. Agbo (2011) described it as a backbone for exchange taking place between the neighbouring countries. Also Bonchuk (2012) sees the border region as being strategic because it is the basic marker of identity, especially the identity of individuals because the conditions for claims to nationality and exercise of rights of citizenship are defined by them. However in spite of the strategic place border communities hold, they are still completely neglected and underdeveloped in Nigeria.

Significant studies have been made in different parts of the world to address the different border issues (Espach and Haering, 2012; Bonchuk, 2010; Afolayan, 2010; Asiwaju, 2006; Ganster, 2005). However, none of these studies addressed travel disadvantage situations in the different border regions. Also, several studies (Bostock, 2001; Battelino, 2009; Currie, et. al. 2009; Dodson, et. al. 2004; Hine, and Mitchell 2003; Naess, 2005; Oyeleye et al, 2013; Olawole et al, 2010; and Travers, 1992) addressed the different transportation problems but none of these studies addressed these situations in rural border areas especially rural border areas of Nigeria. Transport disadvantage in rural border communities of Nigeria is therefore a big issue that needs serious attention and must be addressed.

This paper therefore argues that, in the light of the sensitive and strategic position the border areas hold in the country, Nigerian Government should address their transport challenges as a step towards maintaining rural border liveability and fostering spatial interactions and economic development in the region. This paper therefore explores travel disadvantage in rural border communities of South West Nigeria. The questions addressed in this paper are: 1) what are the pattern of transport disadvantage in rural border communities? and 2) how do the rural border communities cope with transport disadvantage in rural border communities?

\section{The Study Area and Methodology}

Oyo state which is one of the three Border States in South Western Nigeria is located on latitudes $7^{\circ} 22^{\prime}$ and $7^{\circ} 40^{\prime}$ North of the Equator and longitudes 3053' and 4010'East of the Greenwich. It is bounded in the south by Ogun State, in the north by Kwara State, in the west it is partly bounded by Ogun State and partly by the Republic of Benin, while in the East by Osun State as shown in Figure 1. The state has thirty three local government areas out of which Saki-west and Atisbo local government areas were selected for this study because they share border with other countries. The rural border settlements in this area constitute commercial centre for agricultural goods and also the periodic local markets found in the area makes the area a place of exchange between Nigeria and Benin republic. Although the poor state of the roads hinder the thriving of these commercial activities in the area. 


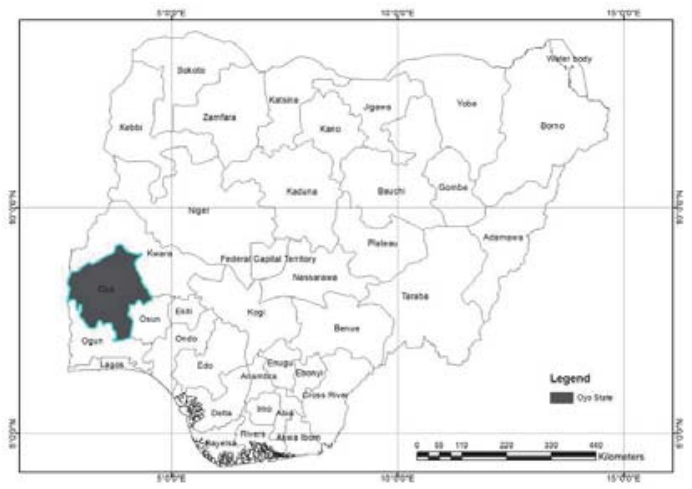

Figure 1: Map of Nigeria showing Oyo State

The research made use of primary data. The primary data were obtained through interview and structured questionnaire administered in the selected rural border communities of Oyo State South Western Nigeria (SWN) using a multistage sampling technique. Two local government areas were selected on the basis of their closeness to the border Saki west and Atisbo local government area as shown in figure 2). After this, four rural border settlements were selected from each of the selected local government areas through simple random selection process. The settlements are: Budowule, Opaba, Abatagboro, Aiyemojuba, Okerete, Obanla, Oritagbagbe and Budo amala. This was followed by selection of every third house in the respective settlements after the first house was randomly selected. A total of 115 duly completed questionnaires administered to the household head in each sampled household were used.

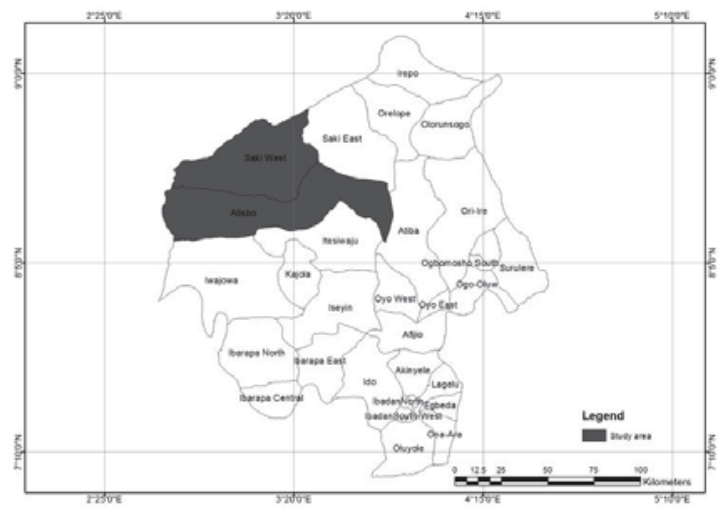

Figure 2: Map of Oyo State showing Saki-west and Atisbo Local Government Areas.

\section{Results and Discussions}

First, pattern of transport disadvantage in rural border communities was presented, this was followed by adaptive measures of the rural border communities to transport disadvantage in the study area?

\subsection{Pattern of Transport Disadvantage in Rural Border Communities}

This section focused on the pattern of transport disadvantage in rural border communities of Oyo. Transport disadvantage in this study was determined in terms of travel mode, travel distance, travel time, and travel cost. These determinants affect people differently across the socio-economic hierarchy of the population. Therefore, this study made use of these determinants, and analysed them subsequently. 


\subsection{Travel Mode}

Several studies have revealed that mode of travel in rural areas of Nigeria include: Trekking, bicycle, motorcycle and public transport. For instance, Tunde and Adeniyi, (2012) in their study discovered that in all the settlements sampled, $38 \%$ used head porterage, $16.7 \%$ used bicycle, $22 \%$ used motorcycle, $18.7 \%$ indicated pick-up vans and $4.6 \%$ used Lorries. However, in rural border communities of Oyo state, Nigeria, the situation is worse off than many other rural communities of Nigeria. There were insufficient modes of transport in this area. For instance, 1\% used public transport, $5 \%$ used motorcycle while $94 \%$ trekked. In the study area, public transport were not readily available, the only available ones were very few, irregular and their movement could not be predicted. These few available vehicles are modified tattered vehicles from major towns like Saki and they are used mainly for Town-village conveyance of passengers and goods. Inter-village and Intra-village movement of the residents are mostly done by trekking thus making them to spend longer time on their travel. This situation according to Oyeleye et al, (2013) makes services remain inaccessible and thus make them disadvantaged in that regard.

\subsection{Travel Distance}

Also analysis of travel distance in the study area revealed that $65 \%$ of the respondents travel between btw $1 \mathrm{~km}$ and $5 \mathrm{~km}$ while the other $35 \%$ travel between $1 \mathrm{~km}$ and half a $\mathrm{km}$ or less. The purpose of their travel is usually to access markets, schools, health centres, water and firewood collection and other domestic needs. The respondents attributed the reason for the long travel distance they trek to the unpredictable movement and unavailability of vehicles (especially public transport). The respondents also linked the unavailability of vehicles to the bad state of the roads which limits the usability of the roads and thus restricts the movement of vehicles. This situation makes the residents take longer period for their travel.

\subsection{Travel Time}

Analysis of travel time of respondent's travel revealed that $50 \%$ of the respondents spend above one hour on their travel, $27 \%$ spend between half an hour and one hour on their travel while $23 \%$ spend at least half an hour on their travel. From this analysis, it can be seen that half of the respondents spend above one hour on their travel. The respondents attributed this much time spent on travel to the distance travelled since majority of the respondents move around by trekking because public vehicles are not available. This is in line with Maher et al. (1992) which explained that people where public transport is not readily available are more likely to be disadvantaged and also spend longer travel times to services

\subsection{Travel cost}

Analysis of travel cost revealed that respondents pay as high as N2500 per Kilometre for cars and as high as N1000per Kilometre for motorcycle. The cost is usually higher when there are goods to convey especially from their farms. However according to analysis of mode of travel revealed above, majority of the respondents move around by trekking because they usually have to pay through their nostrils for the few available vehicles especially when they need to convey their goods. The cost is considered high considering the socio-economic status of the rural households (Fadare, 1989). This also implies that they are travel cost disadvantaged.

\subsection{Adaptive Measures of Rural Border Communities to Travel Disadvantage}

From the discussion above, it was discovered that rural border areas like many other rural areas in Nigeria are transport disadvantaged. These communities in spite of their being transport disadvantaged have sort for means of coping with the situation. For instance the few available vehicles which are usually from the towns are specially modified and adapted to ply the deplorable roads and also to carry goods and passengers more than their normal carrying capacity. For instance, about 8 passengers are packed full inside the vehicle (usually Peugeot 504) and Loads are packed full in their boots. Also passengers and goods are mounted on top of the Peugeot 504 (usually as many as 7 passengers on the roof of the vehicle). This is done in order to convey as many passengers and goods as possible (See plate I). This coping situation is however very dangerous because it puts the lives of the passengers at risk. However the respondents, do not see anything wrong in that. For instance, a woman with baby mounting a modified Peugeot 504 car was interviewed and 
asked what she feels about staying on top of vehicle for her travel. She replied:

"At least, it's still better than having to walk longer distances or watch our goods get spoilt."

Also because of the difficulty in getting vehicles to convey farm produce, and also in order to salvage their products, products are sold to middlemen from towns at extremely low prices who then sell at very exorbitant prices in town. Many of the middlemen come with their trucks and Lorries to convey the goods.

Another strategy the residents use in coping with the situation is communal labour. The community members most times create new paths or widen the existing ones for the passage of vehicles and passengers. They also cut down branches of trees and overgrown weeds on the roads for easy passage.

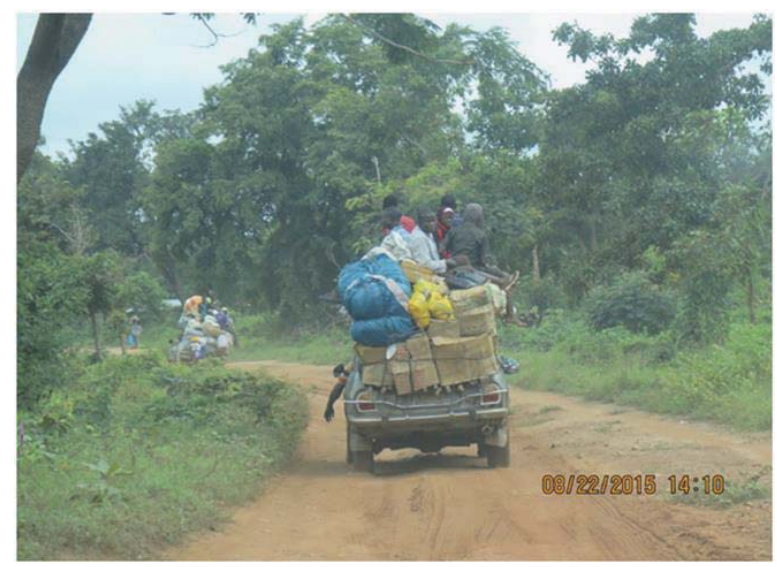

Plate I: Peugeot 504 conveying passengers and loads

\section{Summary and Conclusion}

Travel disadvantage of selected rural border communities of Oyo state, South-western Nigeria was examined in this study. In order to examine the travel disadvantage of residents of the rural border communities their pattern of transport disadvantage and how they cope with the transport disadvantage situation were examined. The pattern of transport disadvantage of the respondents examined were; travel mode, travel distance, travel time, and travel cost. It was discovered in the study that majority of the residents move around by trekking. And many of the respondents trek long distances between btw $1 \mathrm{~km}$ and $5 \mathrm{~km}$ daily. Also they pay exorbitant prices for their travel especially when they need to convey their goods. According to the respondents, the major reason for the travel disadvantage situation was because of the bad condition of the roads which restricts the movement of vehicles. However, in other to salvage the situation, the residents used communal labour to create new paths or widen the existing ones for easy passage of vehicles and passengers. Also the residents sold their products at extremely low prices to middlemen from towns.

Since transport is very important in the development of the border area especially the rural border communities of Oyo state, travel disadvantage situation in these area can be improved by developing basic transport systems in the area through rehabilitation of the existing roads and opening up new ones to allow for ease of movement of people and vehicles. Also, provision of public vehicles by the government should be made a priority in the rural border areas to ensure free movement of the people. Finally, communal labour participation in road maintenance should also be encouraged. The community members must further be encouraged to maintain the existing roads by widening the existing ones for the passage of vehicles and passengers and also cut down branches of trees and overgrown weeds on the roads for easy passage. This study therefore concluded that transport situation in rural border areas of Nigeria needs urgent attention to improve the liveability of the area and the economic development of the area. 


\section{References}

Adeyemi, O. (2001): Moving Nigeria Forward: The Development Planning Approach. Ibadan: University of Ibadan Press.

Adedeji, O.A; Olafiaji, E.M; Omole, F.K; Olanibi, J.A; and Yusuff L. (2014): An assessment of the impact of road transport on rural development: A case study of Obokun Local government area of Osun State. British Journal of Environmental Sciences Vol.2, No.1, pp.34-48.

Adepoju, A. (2005): Creating a Borderless West Africa: Constraints and Prospects for Intra-Regional Migration. Draft Article of the Migration without Border Series. Human Resources Development Centre, Lagos Nigeria.

Afolayan, A.A. (2010): "Trans-Border Movement and Trading Activities across Nigeria-Benin Republic Border. Mediterranean Journal of Social sciences. MCSER Publishing, Rome-Italy 5(1).

Agbo, S.(2011): "Dynamique territoriale à la frontière béninonigériane: rôle des marchés du Sud-Est", Conférence Les Frontières Mobiles, 11e rencontres du Réseau BRIT, Geneva/Grenoble, 6-9 September 2011, pp. 2-3.

Anele, D. (2012): A Brief Note on the Condition of Rural Areas in Nigeria. Vanguard Sunday Perspectives. http://www.vanguardngr. com/2012/01/a-brief-note-on- the- condition-of-rural-areas-in-nigeria.

Asiwaju, A. I. (2006):"Border Security And Transborder Crimes: The Nigerian experience in comparative historical perspective", in Etannibi, O. A. (ed.), Crime And Policing in Nigeria, Challenges and Options, Okoto, Lagos.

Battelino, H. 2009, 'Transport for the transport disadvantaged: A review of service delivery solutions in New South Wales', Transport Policy, vol. 16, pp. 123-129.

Benneth, D.A (2009): Project Genesis: Community Assessment of a Rural South-eastern Arizona Border Community. A project requirement for the Degree of Doctor of Nursing Practice, submitted to the Faculty of College of Nursing, The University of Arizona.

Bostock, L. (2001): "Pathways of Disadvantage? Walking as a mode of transport among low income mothers." Health and Social Care in the Community 9(1): 11-18.

Bonchuck, M. O. (2012): Academic Research in Borderlands Studies: The Challenge of the Transnational Paradigm. American Journal of Social Issues \& Humanities. Vol. 2(5) pp.294-306.

Bonchuck, M. O. (2010): "Cross-Border Crimes, Human Trafficking and the Challenge of Community Policing: A Concept in Search of Policy". Uyo Journal of Humanities, Vol. 14, January.

Bonchuck, M.O. (2014): Nigeria-Cameroon borderland: Prospects of economic cooperation and integration. American Journal of Social Issues and Humanities. 4(2).

Child Family Community Australia (CFCA) Resource Sheet, 2011).

Currie, G. et. al. (2009): 'Investigating links between transport disadvantage, social exclusion and wellbeing in Melbourne--Preliminary results'. Transport Policy, vol. 16, no. 3, pp. 97-105.

Deike, Peter (1998): "Breadwinners, Homemakers and Beasts of Burden: A Gender Perspective on Transport and Mobility." Habitat Debate, vol. 4, No. 2. Nairobi: UNCHS

Dodson, J. et. al. 2004, Transport disadvantage and social status: a review of literature and methods, Griffith University, Brisbane.

Espach, Ralph and Haering, Daniel (2012): Border Insecurity in Central America's Northern Triangle. Washington, DC: Migration Policy Institute and the Woodrow Wilson International Centre for Scholars.

Fadare, S.O (1989): Analysis of factors affecting household trip length in the residential area of Ibadan. Ife Research Publications in Geography, Department of Geography, Obafemi Awolowo University, Ile-Ife, Nigeria.

Fadare, S.O and Salami, B.T (2004): Telephone uses and the travel behaviour of residents in Osogbo, Nigeria: An empirical Analysis. Journal of Transport Geography, Vol 12, Pp159-164.

Filani, M.O. (1988): Mobility and survival. Daily Sketch Friday April 1, Pp5.

Ganster, P. (2005): The state of the Border and the health of its Citizens: Indicators of progress 1993-2023 SCERP Border Environment Research Report 7. San Diego, Calif.: SCREP.

Giuliano,G.(2003): Travel pattern of the elderly; the role of land use.

Hine, J. and F. Mitchell (2003). Transport Disadvantage and Social Exclusion: Exclusionary Mechanisms in Transport in Urban Scotland. Aldershot, UK, Ashgate.

Maher, C., J. Whitelaw, et al. (1992): Mobility and Locational Disadvantage within Australian Cities. Canberra, Department of Prime Minister and Cabinet Social Justice Research Program into Locational Disadvantage.

Naess, P. (2005). "Residential Location Affects Travel Behaviour - But How and Why? The Case of Copenhagen Metropolitan Area." Progress in Planning 63(1): 167-257.

Olawole, M.O., Aloba, O, and Adetunji, M. A. (2010): The place of transport in the attainment of Millenium Development Goals in Rural Areas of Nigeria. Ife Journal of Environmental Design and Management. 4(1), 33-48.

Oyeleye O.I, Toyobo A.E, Adetunji M.A (2013): Travel behaviour of rural people in developing countries. Civil and Environmental Research. Vol.3, No.8.

Tandia, A. (2010);"Borders and borderland identity in Western Senegal Gambia: A comparative perspective of cross-border governance in the neighbourhoods of Senegal, Gambia and Guinea Bissau" African Nebula 2: $19-42$.

Travers Morgan (1992): Strategies to Overcome Transport Disadvantage. Canberra, Department of the Prime Minister and Cabinet Social Justice Research Programme into Locational Disadvantage.

Tunde, A.M and Adeniyi, E.E. (2012): Impact of road transport on agricultural development: A Nigerian example. Ethiopian Journal of 
Environmental Studies and Management EJESM Vol. 5 No. 3.

Weber, A. (2012): Boundaries with issues: Soft Border Management as a solution Perspective Fes Eastern Africa, Friedrich-EbertStiftung, Africa Department, Berlin, Germany.

\section{Appendix}

\section{Research Instrument}

This section explains the research instrument that was used in the study. The instrument include sources and methods of data collection and the statistical techniques that were used in analysing the data collected.

Primary data was used for this study. The primary data was obtained through interview and structured questionnaire administered on house hold heads in the selected rural border communities of Oyo State, South Western Nigeria (SWN) using a multistage sampling technique. In the first stage, two local government areas (Saki west and Atisbo local government areas) were selected on the basis of their closeness to the border). After this, four rural border settlements were selected from each of the selected local government areas through simple random selection process. The settlements are: Budowule, Opaba, Abatagboro, Aiyemojuba, Okerete, Obanla, Oritagbagbe and Budo amala. This was followed by selection of every third house in the respective settlements after the first house was randomly selected. A total of 115 duly completed questionnaires administered to the household head in each sampled household were used. In-depth interview and interactions with selected residents of the communities were also carried out and recorded using audio-visuals like camera and camcorders. These recorded interviews were then transcribed and also photographs were taken and used for the study.

The qualitative data (interviews) were analysed using transcribing while the Quantitative data(Administered questionnaire) obtained were analysed using a number of analytic methods from SPSS package like; tables, frequencies, percentages were used to examine the pattern of transport disadvantage and their adaptive measures in the selected rural border communities Oyo State. The data collection instrument was used to provide information on: pattern of transport disadvantage and the adaptive measures to transport disadvantage in the selected rural border communities Oyo State. 
